\title{
p63 transcriptionally regulates the expression of matrix metallopeptidase 13
}

\author{
Ivana Celardo ${ }^{1}$, Alexey Antonov ${ }^{1,2}$, Ivano Amelio ${ }^{1}$, Margherita Annicchiarico- \\ Petruzzelli ${ }^{3}$ and Gerry Melino \\ 1 Medical Research Council, Toxicology Unit, Leicester University, Leicester LE1 9HN, UK. \\ ${ }^{2}$ Saint-Petersburg State Institute of Technology, Saint- Petersburg, Russia. \\ 3 Biochemistry Laboratory IDI-IRCC; Department of Experimental Medicine and Surgery; University of Rome "Tor Vergata"; \\ Rome, Italy. \\ Correspondence to: Gerry Melino, email: gm89@le.ac.uk \\ Keywords: p63, MMP13, Collagenase, skin, metastasis \\ Received: January 30, $2014 \quad$ Accepted: Febravary 12, $2014 \quad$ Published: Febravary 14, 2014
}

This is an open-access article distributed under the terms of the Creative Commons Attribution License, which permits unrestricted use, distribution, and reproduction in any medium, provided the original author and source are credited.

\section{ABSTRACT:}

p63 is a transcriptional factor belonging to p53 family of genes. Beside the role in cancer, partially shared with p53 and the other member p73, p63 also plays exclusive roles in development and homeostasis of ectodermal/epidermal-related organs. Here we show that p63 transcriptionally controls the expression of the matrix metallopeptidase 13 (MMP13). p63 binds a p53-like responsive element in the human promoter of MMP13, thus promoting the activation of its transcription. The catalytic activity of MMP13 is required in high invasion capacity of metastatic cancer cells, however, although p63 and MMP13 expression correlates in cancer patients, their co-expression does not predict cancer patient survival. Our results demonstrate that p63 directly controls MMP13 expression.

\section{INTRODUCTION}

p63 is a p53-related transcriptional factor, which plays roles in development and cancer. Different promoter regions control the expression of two $\mathrm{N}$-terminal isoforms, TAp63 and $\Delta$ Np63. The P1 promoter, located upstream of exon 1, controls expression of a transactivation domain (TA)-containing isoform (TAp63), whereas the $\mathrm{P} 2$ promoter controls, located in intron 3, promotes the expression of the $\mathrm{N}$-terminal truncated isoform $(\Delta \mathrm{Np} 63)$, which lacks the first TA domain. Alternative splicings at the 3 ' region of $\mathrm{p} 63$ pre-mRNA generates three additional C-terminal isoforms, p63 $\alpha$ (full length), p63 $\beta$ (lacking exon 13) and p63 $\gamma$ (lacking exons 11-14).

In response to the DNA damage TAp63 can induce cell cycle arrest and apoptosis, partially overlapping function of the others p53 family members, p73[1-4] and p53 [5-10]. In addition, overlapping involvement of all three family members have also been described in metabolism of glutamine[11-15] and serine/glycine[16, 17]. TAp63 has been detected at low levels in different tissues, especially following stress[18]. However, the predominant expression is confined in oocytes, where, in response to genotoxic insults, promotes the induction of BH3-only pro-apoptotic BCL-2 family members, PUMA [19-23] and NOXA[24-30]. Thus, TAp63 has been named the 'guardian of the female germline' [31, 32]. However, TAp63 controls also other cell cycle regulators and proapoptotic genes, some of which shared with p53 and p73, including p21[33], Casp-1,2,3,4,5,8,9 [34-37], TNF, TNF-R1, TRAL-R1, -R2 [38-41]. TAp63 also plays a role in metastasis suppression, repressing TGF- $\beta$-mediated invasiveness. Mutant-p53 forms a ternary complex with Smad and p63 [42-46], antagonizing the p63 metastasis suppression function . Overall, the different $\mathrm{N}$-terminal isoform functions, the tissue-specific expression and interaction with other paralogue genes p53 and p73 [47] arise high complexity to p63 function in cancer (for rev. see [48]).

$\triangle$ Np63 is master regulator of epithelial development and differentiation. p63- (lacking all p63 isoforms) [4952] and $\Delta \mathrm{Np} 63^{-/}$selective null-mice [53] present severe development abnormalities, including limb truncations, craniofacial malformations and the lack of an intact epidermis. Moreover, these animals are born without teeth, mammary glands, prostate or skin appendages - 
structures that are highly dependent on proper epithelialmesenchymal interactions. $\triangle \mathrm{Np} 63$ directly drives epidermal morphogenesis and preserves epidermal homeostasis, maintaining basal keratinocyte proliferative potential in adult normal epidermis $[54,55]$, through regulation of crucial transcriptional target genes[56-60] and microRNAs[61-63]. Recently, Flores group has revealed a role for $\Delta \mathrm{Np} 63$ in the reprogram adult somatic cells into multipotent stem cells. They showed that $\Delta \mathrm{Np} 63^{-/-}$epidermal cells express a subset of markers present in embryonic stem cells and fibroblasts induced to pluripotency using Yamanaka factors [64]. p63 has also been proven to be involved in cutaneous wound healing [65], however still little is known about p63 targets genes during re-epithelialization.

Human matrix Metallopeptidase 13 (MMP13), also known as collagenase-3, is a proteolytic enzyme, identified in 1994 by Freij and colleagues [66]. The substrate specificity of MMP13 indicated that this protease exhibits high proteolytic activity toward fibrillar type I, II, and III collagens [67]. It plays crucial roles in physiological processes such as fetal bone development [68], skeletal development [69, 70], articular cartilage and synovial membrane functionality [71]. MMP13 is low expressed in proliferating keratinocytes, but highly induced at the leading edge of skin wound $[72,73]$. Many factors can control keratinocyte migration [65, 74, 75], but the limiting process is the attachment of keratinocytes to fibrillar type I collagen and subsequent degradation of the collagen by collagenolytic MMPs [76-78]. MMP13 overexpression indeed promotes keratinocyte migration, mediating degradation of the collagen and consequent cell detachment from the basal membrane. It has also been proved that MMP13 is involved in re-epithelialization in wound healing in mice [77]. However, other studies raised a debate on this issue, since MMP $13^{-/-}$mice failed to demonstrate significant difference or showed acceleration of wound closure and re-epithelialization [79]. MMPs are generally considered important targets for human diseases where these enzymes have been found overexpressed and/ or where excessive collagen degradation is involved[80, 81]. Pathological states associated to MMP13 upregulation are different type of cancers[82], osteoarthritis[83, 84], and rheumatoid arthritis[85]. In human cancer upregulation of MMP13 contributes to metastasis onset [72]. The catalytic activity of MMP13 may play a role in the high invasion capacity of cancer cells. Degradation of basement membrane is thought to be an early and critical event influencing tumor invasion and metastasis. Thus, MMP13 represents a negative prognostic factor for different cancers [82, 86, 87]. Recently, our group has identified MMP13 as a direct transcriptional target of the p63 homologous, TAp73[88].

Here we describe MMP13 as target of p63. p63 can indeed transcriptionally control the expression of MMP13 by binding its promoter gene and promoting its expression. This finding indicates a novel target gene of p63 that can help to elucidate p63 role in cancer and in the re-epithelialization process during wound healing.

\section{RESULTS AND DISCUSSION}

\section{p63 promotes MMP13 expression}

In a gene expression-profiling analysis on TAp63 and $\Delta \mathrm{Np} 63$ overexpressing cells performed by microarray approaches, we identified important subsets of genes, which potentially might be transcriptionally regulated by p63. Among the genes, whose expression was modulated by both TAp63 and $\Delta \mathrm{Np} 63$ isoforms, we focused on MMP13.

To validate the microarray data, we employed SaOs-2 Tet On cell lines, where expression of TAp63 $\alpha$ or $\Delta \mathrm{Np} 63 \alpha$ can be induced by the tetracycline analog, doxycycline. Real time qPCR, performed in a time course analysis from $0 \mathrm{~h}$ to $24 \mathrm{~h}$ of doxycycline treatment, showed a significant induction of exogenous TAp63 $\alpha$ and $\Delta \mathrm{Np} 63 \alpha$ and a consistent upregulation of the previously reported p63 transcriptional target, p21 (Fig. 1A,B). qPCR on the time course induction of both TAp63 $\alpha$ and $\Delta \mathrm{Np} 63 \alpha$ SaOs-2 cell lines showed a time-dependent upregulation of MMP13, confirming the result of the microarray analysis (Fig. 1A,B). To confirm this regulation at protein level we performed western blot analysis on TAp63 $\alpha$ and $\Delta \mathrm{Np} 63 \alpha \mathrm{SaOs}-2$ cell lines upon doxycycline treatment. Consistently, MMP13 protein levels were upregulated in time-dependent fashion, when HA-tagged TAp63 $\alpha$ and $\Delta \mathrm{Np} 63 \alpha$ were induced (Fig. 1C,D). Notably, detectable levels of MMP13 were already observed in absence of p63 overexpression (time $0 \mathrm{~h}$ ). Being all p53-family members undetectable in parental SaOs-2 cell line, this observation suggested that alternative mechanisms are also involved in transcriptional regulation at least of basal level of MMP13. Overall, our data suggest that p63 controls expression of MMP13.

\section{p63 directly binds human MMP13 promoter}

To deeply investigate the mechanisms by which p63 controls MMP13 expression, we hypostasized that a direct binding of $\mathrm{p} 63$ on MMP13 gene promoter might be responsible of the transcriptional regulation of the gene. To screen MMP13 promoter sequence in order to identify p63 (p53-like) responsive elements (RE), we employed MatInspector Professional software [89]. We analyzed the first $1.6 \mathrm{~Kb}$ upstream the transcriptional start, searching for the p53-like consensus motifs (matrix V\$P53F/P5301), which contained the core sequence CATC. The in silico analysis suggested that region between -345/-370 contained a putative consensus 

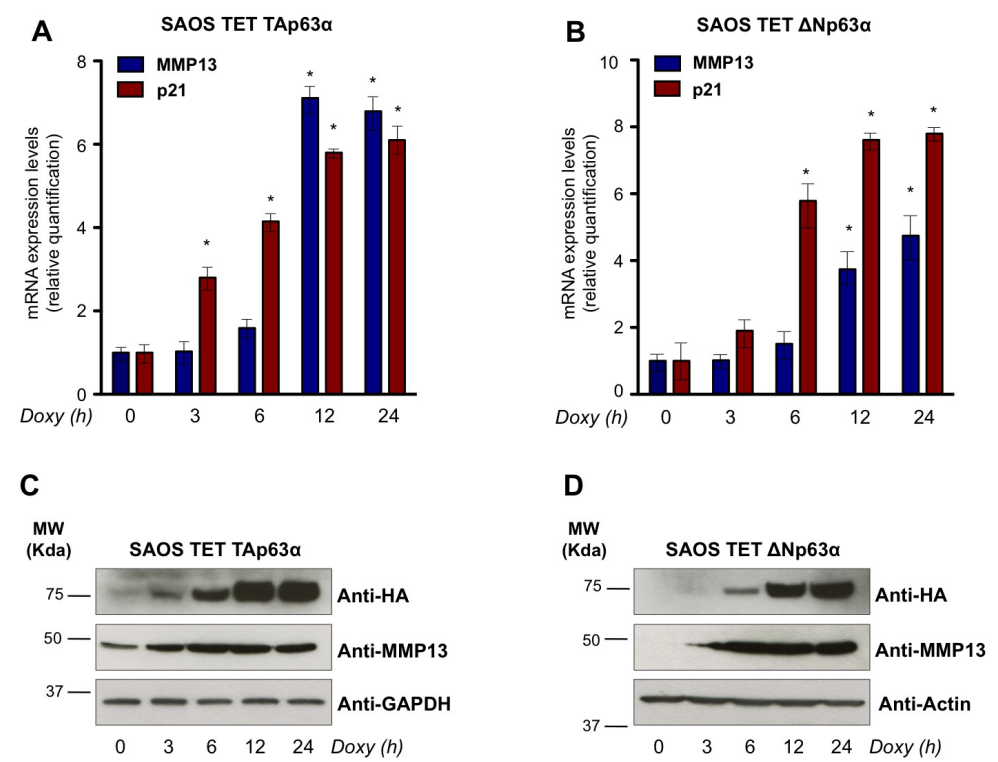

Figure 1: p63 upregulates mRNA and protein levels of MMP13. (a,b) mRNA expression of MMP13 was induced by both p63 isoforms in a time-dependent manner. Levels of MMP13 and of the previously described p63 target gene, p21, were evaluated by real time qPCR following the TAp63 $\alpha$ (a) and $\Delta \mathrm{Np} 63 \alpha$ (b) induction after 3, 6, 12, 24 hours (h) of $4 \mu \mathrm{g} / \mathrm{ml}$ doxycycline (Doxy) treatment in SaOs-2 inducible cells. Relative expression of MMP13 and p21 was normalized using the housekeeping gene, TBP, and calculated as fold induction. Data represent mean $\pm \mathrm{SD}$ of three different experiments. ${ }^{*}, \mathrm{p}<0.01$ (c,d) MMP13 protein induced by TAp63 $\alpha$ (c) and $\Delta \mathrm{Np} 63 \alpha$ (d) at the same time indicated for qPCR. Western blot analysis was performed using the indicated antibodies. GAPDH or Actin were evaluated as control. The experiment is representative of three independent experiments.
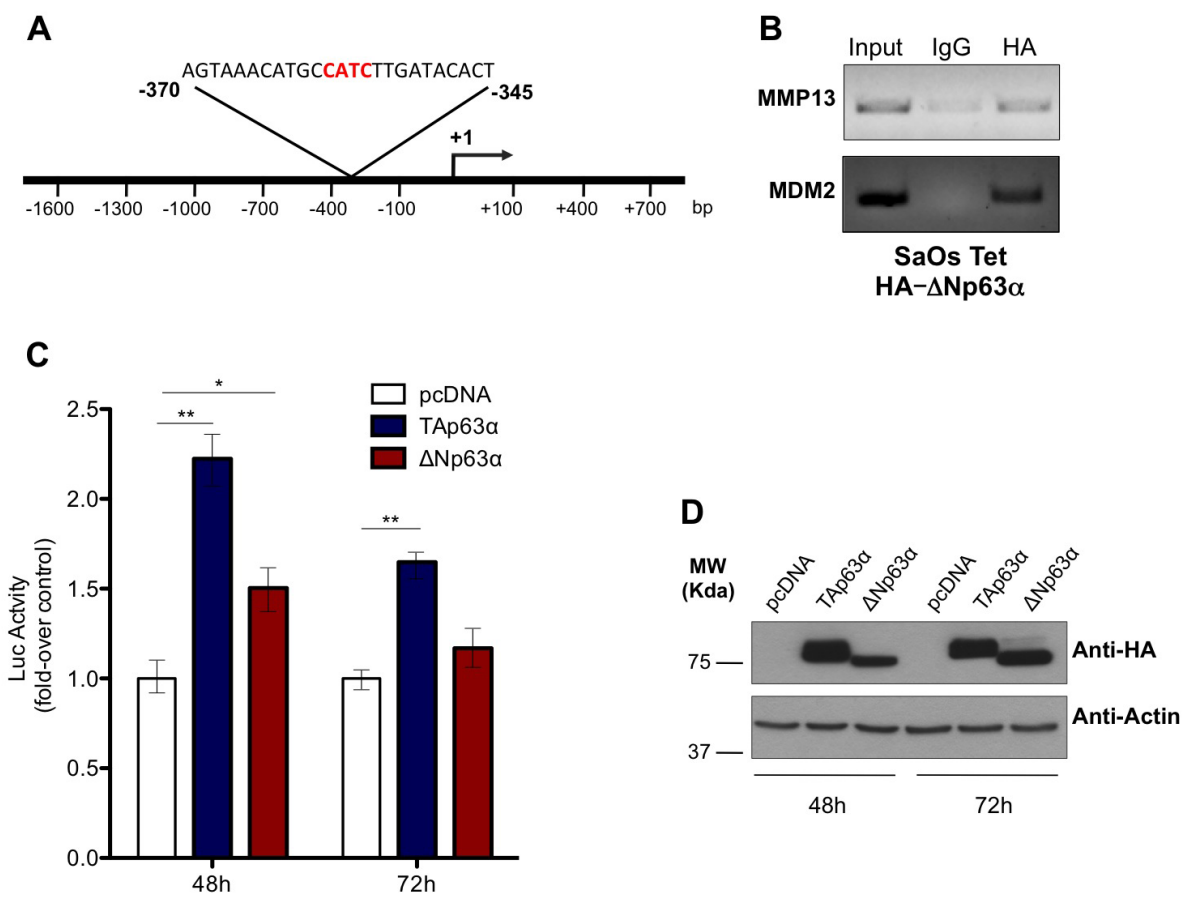

Figure 2: p63 directly binds and transactivates MMP13 promoter. (a) Schematic map of human MMP13 promoter region with the p53-like RE. The insert shows the sequence of p53 RE, located between -345 and -370 bp upstream of transcription-start site. (b) SaOs-2 cells were induced with $4 \mu \mathrm{g} / \mathrm{ml}$ doxycycline for $24 \mathrm{~h}$. The sonicated chromatin was bound to $\triangle \mathrm{Np} 63 \alpha-\mathrm{HA}$ and amplified by PCR with MMP13 primer that recognizes the p53-response element. ChIP on MDM2 promoter was performed as a positive control. Mouse IgG antibody was used as negative control of the ChIP procedure. (c) Both TAp63 $\alpha$ and $\Delta \mathrm{Np} 63 \alpha$ isoforms transactivate MMP13 promoter at $48 \mathrm{~h}$. The MMP13 promoter activity was evaluated after cotransfection with pcDNA vector, TAp63 $\alpha \Delta \mathrm{Np} 63 \alpha$ plasmids. The luciferase assay was performed after $48 \mathrm{~h}$ and $72 \mathrm{~h}$ of cotransfection in $293 \mathrm{~T}$ cells and was normalized with Renilla luciferase vector. The graphs show a mean \pm SD of three different experiments. ${ }^{*}, \mathrm{p}<0.01$; ${ }^{*}, \mathrm{p}<0.05$; (d) Western blot analysis on lysates from luciferase assay was performed as control of p63 protein overexpression. Actin was used as loading control. 
sequence, which potentially might be bound by p63 (Fig. 2A). To experimentally prove the direct binding of p63 on this consensus sequences we designed a ChIP assay. To perform ChIP we used $\Delta \mathrm{Np} 63 \mathrm{SaOs}-2$ Tet On cells, where expression of $\Delta \mathrm{Np} 63$ was induced for $24 \mathrm{~h}$ by doxycycline. The immunoprecipitated chromatin was then subjected to a PCR designed to amplify the p53$\mathrm{RE}$ region included in the MMP13 promoter (Fig. 2A). PCR band was specifically detected only in the anti-HA immunoprecipitated chromatin, when compared with anti-IgG immunoprecipitated control chromatin. Notably, as p63 binding on MDM2 promoter region was already reported, PCR to detect p53 responsive element in MDM2 promoter region was performed as positive control of the experimental procedure. Hence, our ChIP analysis demonstrated the physical interaction of p63 with the p53like RE in the MMP13 promoter, strongly suggesting that MMP13 might be a de novo transcriptional target gene of p63 (Fig. 2B).

\section{p63 activates transcriptional regulation of MMP13 promoter}

To elucidate whether the direct binding of p63 on MMP13 promoter was functional, the -1600 bp upstream the transcriptional start were inserted into luciferase reporter plasmid to evaluate the transcriptional ability of p63 on this genomic region (Fig. 2A). The promoter was then cotransfected into $293 \mathrm{~T}$ cells together with HAtagged TAp $63 \alpha$ or $\Delta \mathrm{Np} 63 \alpha$ or empty control vector. $48 \mathrm{~h}$ after transfection, increased luciferase activity confirmed a significant transcriptional activation of MMP13 promoter by both $\mathrm{TAp} 63 \alpha$ and $\Delta \mathrm{Np} 63 \alpha$ (respectively 2.3- and 1.5-fold increase). Consistently, after $72 \mathrm{~h}$ of transfection similar trend was confirmed, although only TAp63 $\alpha$ overexpressing cells provided a statistical significant increase (Fig. 2C). Notably, western blot analysis confirmed good transfection efficiency for both TAp63 $\alpha$ and $\Delta \mathrm{Np} 63 \alpha$ at the two time points (Fig. 2D). These data demonstrate that p63 binding on the binding sequences located at -370/-345 from transcription-start site is functionally active to promote MMP13 expression. However, the qPCR results shown in figure 1, where p63-dependent upregulation of MMP13 showed up to 7-fold increase, would suggest that, besides this p53-RE, additional consensus sequences might be involved in the transcriptional regulation of MMP13 by $\mathrm{p} 63$.

\section{p63 correlates with MMP13 expression in cancer patients}

To confirm the existence and to assess the relevance of p63/MMP13 axis, we searched for expression correlation of these two genes in human cancer patient datasets. Breast cancer represents a heterogeneous group of diseases with different biological and morphological features, although strong efforts have been placed in identification of biomarkers of high-grade/metastatic forms of this disease[90-92], still much is expected to improve prognostic and predictive marker assessment. Melanoma is among the most aggressive cancer, with high incidence of metastasis and advanced stages progression [93-96]. Therefore to confirm p63/MMP13 relevance in cancer, we selected two cancer datasets: a breast carcinoma cohort [97] of 87 samples and a melanoma cohort, which included 25 melanomas [98], 9 non-neoplastic nevus and 3 normal samples. Coexpression analysis showed direct association between p63 and MMP13 mRNA level in both the datasets analysed. The breast cancer dataset presented a correlation factor of 0.293, while the melanoma dataset of 0.298 (Fig. $3 \mathrm{~A}, \mathrm{~B})$. These data confirm a coexpression and a direct correlation of p63 and MMP13 in human cancers. The melanoma dataset included normal and non-neoplastic specimens. Interestingly, a clear switch from high p63/ MMP13 expression to low p63/MMP13 occurred in the transition towards the malignant state of melanocytes (Fig. 3B). To further investigate the function of p63/MMP13 in cancer, we decided to analysed MMP13 ability to function as prognostic factor of human cancer. We used three different publicly available datasets of human cancer, which included patient survival information (lung adenocarcinoma GSE31210, breast cancer GSE2034, and liposarcoma GSE30929). Patient datasets were clustered according to the expression of MMP13 (high expressing, low expressing). Kaplan-Mayer curve for survival estimation showed that a high MMP13 expression was predictive of poor survival (Fig. 4A-C), suggesting that MMP13 plays an important role in cancer aggressiveness. In order to elucidate whether $\mathrm{p} 63$ functions as a controller of MMP13 expression in cancer, we evaluated the biological consequence of p63/MMP13 coexpression in cancer patients. We selected the datasets analyzed in figure 4 (lung adenocarcinoma GSE31210, breast cancer GSE2034, and liposarcoma GSE30929) and we split the samples in two cohorts. The first cohort included all the samples to maximize positive correlation between p63 and MMP13, while in the second cohort all the other samples were included (Fig. 5). Thus, we clustered the dataset in two biological groups: one where p63/MMP13 axis was present (p63/MMP13 interaction), and second in which it was absent (p63/MMP13 NO interaction). Performing Kaplan-Mayer survival estimation the two cohorts did not show any significant difference in the survival expectation (Fig. 5). These data suggest that, although p63 is able to control MMP13 expression, it is very unlikely this axis plays any relevant role in cancer biology.

\section{CONCLUSION}

p63 plays fundamental roles in development and homeostasis of the epidermis as well as in cancer. 


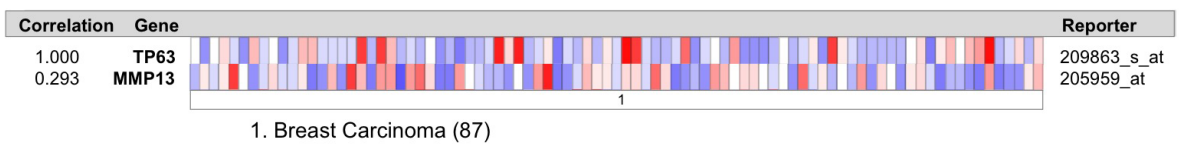

\section{B Haqq Melanoma}

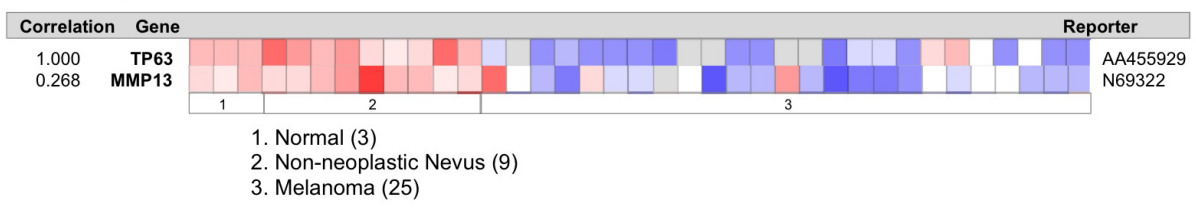

Figure 3: p63 and MMP13 expression directly correlates in human breast and melanoma cancers. (a,b) Expression data from Oncomine website (www.oncomine.org). We used the following filters: gene 'TP63'; Analysis Type: 'Coexpression analysis'; Cancer Type: Breast (a) or Melanoma Cancer (b). The colour changes according to a weaker (blue) or higher (red) expression, passing by white, with fluctuating colour intensity. The reporters indicate probes used for the analysis.
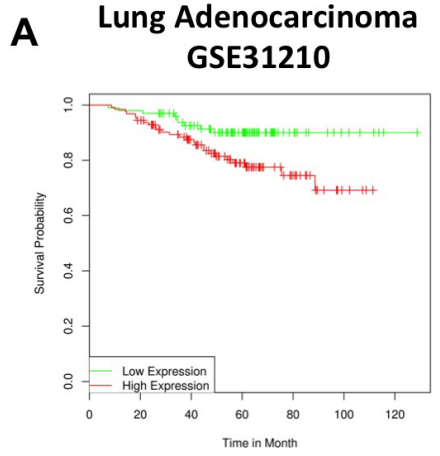

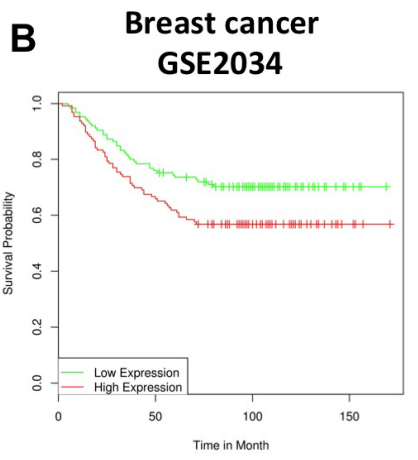

\section{Liposarcoma}

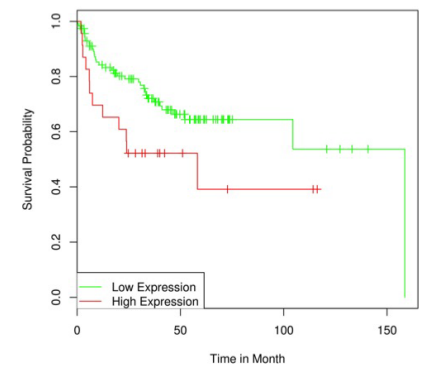

Figure 4: MMP13 expression is a negative prognostic marker in human cancers. (a-c) Three different human cancer datasets have been analysed: GSE31210 (Lung adenocarcinoma a), GSE2034 (Breast cancer b), GSE30929 (Liposarcoma c). The panels represent patient survival estimation of MMP13 high expressing compared to low expressing groups.
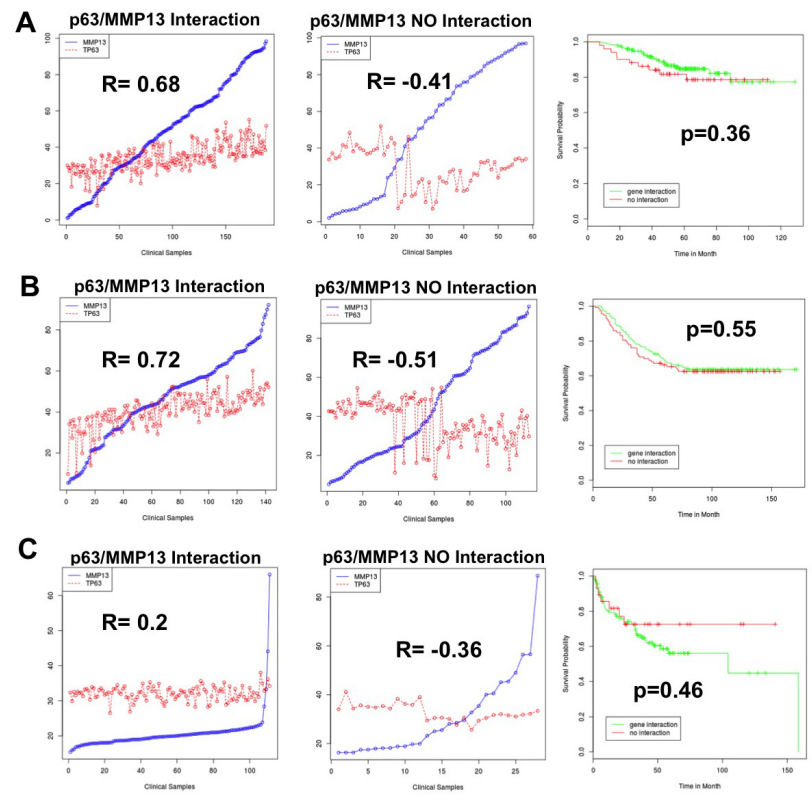

Figure 5: p63/MMP13 correlation does not function as prognostic marker in cancer. Three different human cancer datasets have been analysed: lung adenocarcinoma GSE31210 (a), breast cancer GSE2034 (b), liposarcoma GSE30929 (c). (a-c) Left and central panels respectively represent p63 and MMP13 expression profiles in the cohorts 1 (p63/MMP13 Interaction) and cohorts 2 (p63/MMP13 NO Interaction). Right panels represent patient survival estimation in the two groups. 
Here we have identified the matrix metallopeptidase 13, MMP13, as direct transcriptional target of p63. A wide overlapping involvement of all p53-family occurs in the transcriptional regulation of MMP13. We have indeed recently demonstrated that MMP-13 is a direct downstream target of p73 [88]. In addition wt p53 and mutant p53 (mp53) exert opposite regulation on MMP13 expression. Wt p53 represses MMP13, while mp53 promotes MMP13 expression in wt p53 expressing cells[99]. This regulation is in line with pro-metastatic ability of mp53 (gain-of-function feature), however our data do not suggest a direct involvement of p63/MMP13 axis in cancer progression. Our clinical analyses suggest that p63-dependent regulation of MMP13 has not direct impact on survival outcome of cancer patient. This observation tempts to speculate that MMP13 regulation by p63 may represent an important axis in epidermal wound healing and skin homeostasis. Being both available p63 and MMP13 animal models, further investigations will clarify the relationship between these two genes in order to provide a deeper understanding of their the biological relevance of their interaction.

\section{MATERIALS AND METHODS}

\section{Cell cultures and Transfection}

All cell lines were grown at $37^{\circ} \mathrm{C}$ in a humidified atmosphere of $5 \% \mathrm{CO}_{2}$ in air. SaOs-2-Tet-On cells were maintained in RPMI, $10 \%$ (vol/vol) Tet-free FCS (Clontech), penicillin/streptomycin 1 unit/ml (Gibco) and $250 \mathrm{mM}$ L-glutamine (Gibco). A Tet-responsive transcriptional activator rtTA was used to obtain $\mathrm{SaOs}-2$ clones with the inducible expression of TA $\alpha$ and $\Delta \mathrm{N} \alpha \mathrm{p} 63$ isoforms (Tet-On system). 293 T cells were maintained in RPMI, 10\% (vol/vol) FCS (Invitrogen) $250 \mathrm{mM}$ sodium pyruvate (Gibco), penicillin/streptomycin 1 unit $/ \mathrm{ml}$ (Gibco) and $250 \mathrm{mM}$ L-glutamine (Gibco).

\section{Cell transfection and luciferase assay}

$293 \mathrm{~T}$ cells were seeded $24 \mathrm{~h}$ before the transfection at density of $1 \times 10^{5}$ in 12 -well dishes. The day after, cells were co-transfected with 300ng/well of HA-tagged pGL3 vector or TAp $63 \alpha$ and $\Delta \mathrm{Np} 63 \alpha$ plasmids, $100 \mathrm{ng} /$ well MMP13 luciferase reporter plasmid and 2ng/well pRL-cytomegalovirus vector. Transfection was carried out by Effectene reagent (Qiagen) according to the manufacturer's instructions. After $48 \mathrm{~h}$ and $72 \mathrm{~h}$ from the transfection, the luciferase activities of cellular extracts were detected using a Dual-Luciferase Reporter Assay System (Genecopoeia). Renilla luciferase activity was used to normalize the transfection efficiency. Light emission was measured over 5 s using a luminometer (with
Glomax 96 Microplate Luminometer, Promega (Madison, WI, USA)).

\section{Western Blotting}

Proteins were extracted with RIPA buffer containing mixture inhibitors (Roche), followed by homogenization by using QIAshredder (Qiagen) and evaluation of concentration by using a Bradford dye-based assay (Bio-Rad). $50 \mu \mathrm{g}$ of total proteins were loaded on $10 \%$ SDS/PAGE and transferred to polyvinylidene difluoride membranes (Hybond; GE Healthcare), followed by immunoblotting with appropriate antibodies. The blots were then incubated with peroxidase linked secondary antibodies followed by enhanced-chemiluminescent detection using ECL kit (Amersham). Primary antibodies were used as followed: anti-HA $1: 100$ (Covance); antiMMP13 1:500 (Millipore); anti-actin and anti-GAPDH 1 : 10.000 (Sigma-Aldrich).

\section{RNA extraction and quantitative real-time PCR}

After $4 \mu \mathrm{g} / \mathrm{ml}$ doxycycline induction, total RNA was extracted from TAp63 $\alpha$ and $\Delta \mathrm{Np} 63 \alpha \mathrm{SaOs}-2$ cells by using the RNeasy Mini Kit (Qiagen) and quantified by spectrophotometric analysis. Reverse transcription from $1 \mu \mathrm{g}$ of total RNA was performed using InPromII kit (Promega); 1/5 of cDNA obtained was used for real-time PCR. The primers used for the real-time PCR were: MMP13 +ATATGACTATGCGTGGCTGGAAC, _CCATGTGTCCCATTTGTGGTGTG;

p21 +TGGGGATGTCCGTCAGAAC, GGCGTTTGGAGTGGTAGAAATC; TBP +TCAAACCCAGAATTGTTCTCCTTAT, CCTGAATCCCTTTAGAATAGGGTAGA. SYBR green ready mix (Applied Biosystems) was used to perform the real-time PCR. For the quantity normalization we used TBP as housekeeping gene; relative quantification of gene expression was analyzed according to the method of $2^{-\Delta \Delta \mathrm{Ct}}$ reported in the User Bulletin no. 2 and the Relative Quantification software version 1.3 of Applied Biosystems.

\section{Analysis of promoter region}

Analysis of promoter region was performed using Math-Inspector Professional software and the TRANSFAC database on a region of $1600 \mathrm{~kb}$ upstream of the transcription-start site of the human MMP13. The analysis highlighted a $25 \mathrm{bp}$ region containing a p53-like RE site. The MMP13 promoter plasmid was purchased from Genecopoeia (vector: pEZX-PG02). 


\section{Chromatin immunoprecipitation assay}

After induction of $\Delta \mathrm{Np} 63 \alpha$ expression obtained by doxycycline $24 \mathrm{~h}$ treatment $(4 \mu \mathrm{g} / \mathrm{ml}), \quad$ SaOs- 2 cells were collected and fixed in $37 \%$ formaldehyde. Sonication was used to shear the chromatin, followed by immunoprecipitation with or without $10 \mu \mathrm{l}$ of antiHA antibody (Covance) for $2 \mathrm{~h}$ using ChIP assay kit (Invitrogen). For the PCR we used the following primers: MMP13 +GCACCTCCAAGTCATCAAGC, _TGTGGGAAGAAGCAGAGAGTAG; MDM2 + GGTTGACTCAGCTTTTCCTCTTG, GGAAAATGCATGGTTTAAATAGCC.

\section{Bioinformatics analyses}

Gene expression datasets GSE31210, GSE2034, GSE30929 were downloaded from the GEO omnibus repository. Gene expression rank reflects relative mRNA expression level and is more consistent as it requires no normalization and thus introduces no normalization bias. Gene expression values were transformed into rank expression values on the scale from 100 to 0 . Rank value 55 means 55 per cent of probes in the sample have lower measured expression values. We use Pearson coefficient as a measure of correlation between expression profiles. Our primary aim is to divide samples in the dataset in two cohorts so that to maximize positive correlation between expression profiles of $\mathrm{p} 63$ and MMP13 in cohort 1 and to minimize positive correlation in cohort 2 . We start with all samples in cohort 1 and no samples in cohort 2 . We compute correlation between $\mathrm{p} 63$ and MMP13 expression profiles in cohort 1 as well as compute the changes in correlation if one sample from the cohort would be removed. The sample with maximal effect on correlation (maximal increase in positive correlation) is moved from cohort 1 to cohort 2 . The same procedure is repeated until there would be no one sample which could be removed from cohort 1 , so to increase positive correlation between p63 and MMP13. The separation of patients into "cohort 1 " and "cohort 2" along with survival information is then used to find any statistical differences in survival outcome. The $\mathrm{R}$ statistical package is used to perform survival analyses and to draw KMplots.

\section{CONFLICT OF INTEREST}

The authors declare no conflict of interest.

\section{AKNOWLEDGMENTS}

This work has been supported by the Medical Research Council, UK, Associazione Italiana per la Ricerca sul Cancro (AIRC) Grants 2011-IG11955 and
AIRC 5xmile (\#9979) (to. G.M.).

\section{REFERENCES}

1. Flores ER, Tsai KY, Crowley D, Sengupta S, Yang A, McKeon F and Jacks T. p63 and p73 are required for p53dependent apoptosis in response to DNA damage. Nature. 2002; 416(6880):560-564.

2. Wilhelm MT, Rufini A, Wetzel MK, Tsuchihara K, Inoue S, Tomasini R, Itie-Youten A, Wakeham A, ArsenianHenriksson M, Melino G, Kaplan DR, Miller FD and Mak TW. Isoform-specific p73 knockout mice reveal a novel role for delta $\mathrm{Np} 73$ in the DNA damage response pathway. Genes Dev. 2010; 24(6):549-560.

3. Grespi F, Amelio I, Tucci P, Annicchiarico-Petruzzelli M and Melino G. Tissue-specific expression of p73 C-terminal isoforms in mice. Cell Cycle. 2012; 11(23):4474-4483.

4. Sayan BS, Yang AL, Conforti F, Tucci P, Piro MC, Browne GJ, Agostini M, Bernardini S, Knight RA, Mak TW and Melino G. Differential control of TAp73 and DeltaNp73 protein stability by the ring finger ubiquitin ligase PIR2. Proc Natl Acad Sci U S A. 2010; 107(29):12877-12882.

5. Lowe SW, Ruley HE, Jacks T and Housman DE. p53dependent apoptosis modulates the cytotoxicity of anticancer agents. Cell. 1993; 74(6):957-967.

6. Valentino T, Palmieri D, Vitiello M, Pierantoni GM, Fusco A and Fedele M. PATZ1 interacts with p53 and regulates expression of p53-target genes enhancing apoptosis or cell survival based on the cellular context. Cell Death Dis. 2013; 4:e963.

7. Fan YH, Cheng J, Vasudevan SA, Dou J, Zhang H, Patel RH, Ma IT, Rojas Y, Zhao Y, Yu Y, Shohet JM, Nuchtern JG, Kim ES and Yang J. USP7 inhibitor P22077 inhibits neuroblastoma growth via inducing p53-mediated apoptosis. Cell Death Dis. 2013; 4:e867.

8. Lowe SW, Schmitt EM, Smith SW, Osborne BA and Jacks T. p53 is required for radiation-induced apoptosis in mouse thymocytes. Nature. 1993; 362(6423):847-849.

9. Lv C, Hong Y, Miao L, Li C, Xu G, Wei S, Wang B, Huang $\mathrm{C}$ and Jiao B. Wentilactone A as a novel potential antitumor agent induces apoptosis and G2/M arrest of human lung carcinoma cells, and is mediated by HRas-GTP accumulation to excessively activate the Ras/Raf/ERK/ p53-p21 pathway. Cell Death Dis. 2013; 4:e952.

10. Rufini A, Tucci P, Celardo I and Melino G. Senescence and aging: the critical roles of p53. Oncogene. 2013; 32(43):5129-5143.

11. Suzuki S, Tanaka T, Poyurovsky MV, Nagano H, Mayama T, Ohkubo S, Lokshin M, Hosokawa H, Nakayama T, Suzuki Y, Sugano S, Sato E, Nagao T, Yokote K, Tatsuno I and Prives C. Phosphate-activated glutaminase (GLS2), a p53-inducible regulator of glutamine metabolism and reactive oxygen species. Proc Natl Acad Sci U S A. 2010; 107(16):7461-7466. 
12. Hu W, Zhang C, Wu R, Sun Y, Levine A and Feng Z. Glutaminase 2, a novel p53 target gene regulating energy metabolism and antioxidant function. Proc Natl Acad Sci U S A. 2010; 107(16):7455-7460.

13. Giacobbe A, Bongiorno-Borbone L, Bernassola F, Terrinoni A, Markert EK, Levine AJ, Feng Z, Agostini M, Zolla L, Agro AF, Notterman DA, Melino G and Peschiaroli A. p63 regulates glutaminase 2 expression. Cell Cycle. 2013; 12(9):1395-1405.

14. Velletri T, Romeo F, Tucci P, Peschiaroli A, AnnicchiaricoPetruzzelli M, Niklison-Chirou MV, Amelio I, Knight RA, Mak TW, Melino G and Agostini M. GLS2 is transcriptionally regulated by $\mathrm{p} 73$ and contributes to neuronal differentiation. Cell Cycle. 2013; 12(22):35643573.

15. He Z, Liu H, Agostini M, Yousefi S, Perren A, Tschan MP, Mak TW, Melino G and Simon HU. p73 regulates autophagy and hepatocellular lipid metabolism through a transcriptional activation of the ATG5 gene. Cell Death Differ. 2013; 20(10):1415-1424.

16. Amelio I, Markert EK, Rufini A, Antonov AV, Sayan BS, Tucci P, Agostini M, Mineo TC, Levine AJ and Melino G. p73 regulates serine biosynthesis in cancer. Oncogene. 2013.

17. Maddocks OD, Berkers CR, Mason SM, Zheng L, Blyth K, Gottlieb E and Vousden KH. Serine starvation induces stress and p53-dependent metabolic remodelling in cancer cells. Nature. 2013; 493(7433):542-546.

18. Suh EK, Yang A, Kettenbach A, Bamberger C, Michaelis AH, Zhu Z, Elvin JA, Bronson RT, Crum CP and McKeon F. p63 protects the female germ line during meiotic arrest. Nature. 2006; 444(7119):624-628.

19. Kerr JB, Hutt KJ, Michalak EM, Cook M, Vandenberg CJ, Liew SH, Bouillet P, Mills A, Scott CL, Findlay JK and Strasser A. DNA damage-induced primordial follicle oocyte apoptosis and loss of fertility require TAp63-mediated induction of Puma and Noxa. Mol Cell. 2012; 48(3):343352.

20. Adlakha YK and Saini N. miR-128 exerts pro-apoptotic effect in a $\mathrm{p} 53$ transcription-dependent and -independent manner via PUMA-Bak axis. Cell Death Dis. 2013; 4:e542.

21. Yuan Z, Cao K, Lin C, Li L, Liu HY, Zhao XY, Liu L, Deng HX, Li J, Nie CL and Wei YQ. The p53 upregulated modulator of apoptosis (PUMA) chemosensitizes intrinsically resistant ovarian cancer cells to cisplatin by lowering the threshold set by $\mathrm{Bcl}-\mathrm{x}(\mathrm{L})$ and Mcl-1. Mol Med. 2011; 17(11-12):1262-1274.

22. Guadagno J, Xu X, Karajgikar M, Brown A and Cregan SP. Microglia-derived TNFalpha induces apoptosis in neural precursor cells via transcriptional activation of the Bcl-2 family member Puma. Cell Death Dis. 2013; 4:e538.

23. Garrison SP, Phillips DC, Jeffers JR, Chipuk JE, Parsons MJ, Rehg JE, Opferman JT, Green DR and Zambetti GP. Genetically defining the mechanism of Puma- and Bim- induced apoptosis. Cell Death Differ. 2012; 19(4):642-649.

24. Park SY, Jeong MS and Jang SB. In vitro binding properties of tumor suppressor p53 with PUMA and NOXA. Biochem Biophys Res Commun. 2012; 420(2):350-356.

25. Rooswinkel RW, van de Kooij B, Verheij M and Borst J. Bcl-2 is a better ABT-737 target than Bcl-xL or Bcl-w and only Noxa overcomes resistance mediated by Mcl-1, Bfl-1, or Bcl-B. Cell Death Dis. 2012; 3:e366.

26. Villunger A, Michalak EM, Coultas L, Mullauer F, Bock G, Ausserlechner MJ, Adams JM and Strasser A. p53- and drug-induced apoptotic responses mediated by BH3-only proteins puma and noxa. Science. 2003; 302(5647):10361038.

27. Seo YW, Shin JN, Ko KH, Cha JH, Park JY, Lee BR, Yun CW, Kim YM, Seol DW, Kim DW, Yin XM and Kim TH. The molecular mechanism of Noxa-induced mitochondrial dysfunction in p53-mediated cell death. J Biol Chem. 2003; 278(48):48292-48299.

28. Happo L, Phipson B, Smyth GK, Strasser A and Scott CL. Neither loss of Bik alone, nor combined loss of Bik and Noxa, accelerate murine lymphoma development or render lymphoma cells resistant to DNA damaging drugs. Cell Death Dis. 2012; 3:e306.

29. Ehrhardt H, Hofig I, Wachter F, Obexer P, Fulda S, Terziyska N and Jeremias I. NOXA as critical mediator for drug combinations in polychemotherapy. Cell Death Dis. 2012; 3:e327.

30. Craxton A, Butterworth M, Harper N, Fairall L, Schwabe J, Ciechanover A and Cohen GM. NOXA, a sensor of proteasome integrity, is degraded by $26 \mathrm{~S}$ proteasomes by an ubiquitin-independent pathway that is blocked by MCL1. Cell Death Differ. 2012; 19(9):1424-1434.

31. Amelio I, Grespi F, Annicchiarico-Petruzzelli $M$ and Melino G. p63 the guardian of human reproduction. Cell Cycle. 2012; 11(24):4545-4551.

32. Levine AJ, Tomasini R, McKeon FD, Mak TW and Melino G. The p53 family: guardians of maternal reproduction. Nat Rev Mol Cell Biol. 2011; 12(4):259-265.

33. Lee MS, Seo J, Choi DY, Lee EW, Ko A, Ha NC, Yoon JB, Lee HW, Kim KP and Song J. Stabilization of p21 (Cip1/ WAF1) following Tip60-dependent acetylation is required for $\mathrm{p} 21$-mediated DNA damage response. Cell Death Differ. 2013; 20(4):620-629.

34. Celardo I, Grespi F, Antonov A, Bernassola F, Garabadgiu AV, Melino G and Amelio I. Caspase-1 is a novel target of p63 in tumor suppression. Cell Death Dis. 2013; 4:e645.

35. Bouchier-Hayes L and Green DR. Caspase-2: the orphan caspase. Cell Death Differ. 2012; 19(1):51-57.

36. Gressner O, Schilling T, Lorenz K, Schulze Schleithoff E, Koch A, Schulze-Bergkamen H, Lena AM, Candi E, Terrinoni A, Catani MV, Oren M, Melino G, Krammer $\mathrm{PH}$, Stremmel W and Muller M. TAp63alpha induces apoptosis by activating signaling via death receptors and mitochondria. Embo J. 2005; 24(13):2458-2471. 
37. Puccini J, Dorstyn L and Kumar S. Caspase-2 as a tumour suppressor. Cell Death Differ. 2013; 20(9):1133-1139.

38. Dohn M, Zhang $\mathrm{S}$ and Chen X. p63alpha and DeltaNp63alpha can induce cell cycle arrest and apoptosis and differentially regulate p53 target genes. Oncogene. 2001; 20(25):3193-3205.

39. Lu C, Lu S, Liang W, Li J, Dou X, Bian C, Shi D, Liao L and Zhao RC. TAp63alpha mediates chemotherapeutic agentinduced apoptosis in human bone marrow mesenchymal stem cells. Stem Cells Dev. 2011; 20(8):1319-1326.

40. Guo X, Keyes WM, Papazoglu C, Zuber J, Li W, Lowe SW, Vogel H and Mills AA. TAp63 induces senescence and suppresses tumorigenesis in vivo. Nat Cell Biol. 2009; 11(12):1451-1457.

41. Lascano V, Zabalegui LF, Cameron K, Guadagnoli M, Jansen M, Burggraaf M, Versloot M, Rodermond H, van der Loos C, Carvalho-Pinto CE, Kalthoff H, Medema JP and Hahne M. The TNF family member APRIL promotes colorectal tumorigenesis. Cell Death Differ. 2012; 19(11):1826-1835.

42. Adorno M, Cordenonsi M, Montagner M, Dupont S, Wong C, Hann B, Solari A, Bobisse S, Rondina MB, Guzzardo V, Parenti AR, Rosato A, Bicciato S, Balmain A and Piccolo S. A Mutant-p53/Smad complex opposes p63 to empower TGFbeta-induced metastasis. Cell. 2009; 137(1):87-98.

43. Tucci P, Agostini M, Grespi F, Markert EK, Terrinoni A, Vousden KH, Muller PA, Dotsch V, Kehrloesser S, Sayan BS, Giaccone G, Lowe SW, Takahashi N, Vandenabeele P, Knight RA, Levine AJ, et al. Loss of p63 and its microRNA-205 target results in enhanced cell migration and metastasis in prostate cancer. Proceedings of the National Academy of Sciences of the United States of America. 2012; 109(38):15312-15317.

44. Montagner M, Enzo E, Forcato M, Zanconato F, Parenti A, Rampazzo E, Basso G, Leo G, Rosato A, Bicciato S, Cordenonsi M and Piccolo S. SHARP1 suppresses breast cancer metastasis by promoting degradation of hypoxiainducible factors. Nature. 2012; 487(7407):380-384.

45. Amelio I and Melino G. The "Sharp" blade against HIFmediated metastasis. Cell Cycle. 2012; 11(24):4530-4535.

46. Tirino V, Camerlingo R, Bifulco K, Irollo E, Montella R, Paino F, Sessa G, Carriero MV, Normanno N, Rocco G and Pirozzi G. TGF-beta1 exposure induces epithelial to mesenchymal transition both in CSCs and non-CSCs of the A549 cell line, leading to an increase of migration ability in the CD133+ A549 cell fraction. Cell Death Dis. 2013; 4:e620.

47. Alexandrova EM, Talos F and Moll UM. p73 is dispensable for commitment to neural stem cell fate, but is essential for neural stem cell maintenance and for blocking premature differentiation. Cell death and differentiation. 2013; 20(2):368

48. Melino G. p63 is a suppressor of tumorigenesis and metastasis interacting with mutant p53. Cell Death Differ.
2011; 18(9):1487-1499.

49. Mills AA, Zheng B, Wang XJ, Vogel H, Roop DR and Bradley A. p63 is a p53 homologue required for limb and epidermal morphogenesis. Nature. 1999; 398(6729):708713.

50. Yang A, Schweitzer R, Sun D, Kaghad M, Walker N, Bronson RT, Tabin C, Sharpe A, Caput D, Crum C and McKeon F. p63 is essential for regenerative proliferation in limb, craniofacial and epithelial development. Nature. 1999; 398(6729):714-718.

51. Candi E, Rufini A, Terrinoni A, Giamboi-Miraglia A, Lena AM, Mantovani R, Knight R and Melino G. DeltaNp63 regulates thymic development through enhanced expression of FgfR2 and Jag2. Proc Natl Acad Sci U S A. 2007; 104(29):11999-12004.

52. Terrinoni A, Serra V, Bruno E, Strasser A, Valente E, Flores ER, van Bokhoven H, Lu X, Knight RA and Melino G. Role of p63 and the Notch pathway in cochlea development and sensorineural deafness. Proc Natl Acad Sci U S A. 2013; 110(18):7300-7305.

53. Romano RA, Smalley K, Magraw C, Serna VA, Kurita T, Raghavan S and Sinha S. DeltaNp63 knockout mice reveal its indispensable role as a master regulator of epithelial development and differentiation. Development. 2012; 139(4):772-782.

54. Senoo M, Pinto F, Crum CP and McKeon F. p63 Is essential for the proliferative potential of stem cells in stratified epithelia. Cell. 2007; 129(3):523-536.

55. Rufini S, Lena AM, Cadot B, Mele S, Amelio I, Terrinoni A, Desideri A, Melino G and Candi E. The sterile alpha-motif (SAM) domain of p63 binds in vitro monoasialoganglioside (GM1) micelles. Biochem Pharmacol. 2011; 82(10):12621268.

56. Romano RA, Birkaya B and Sinha S. A functional enhancer of keratin14 is a direct transcriptional target of deltaNp63. J Invest Dermatol. 2007; 127(5):1175-1186.

57. Borrelli S, Testoni B, Callari M, Alotto D, Castagnoli C, Romano RA, Sinha S, Vigano AM and Mantovani R. Reciprocal regulation of $\mathrm{p} 63$ by $\mathrm{C} / \mathrm{EBP}$ delta in human keratinocytes. BMC Mol Biol. 2007; 8:85.

58. Lena AM, Cipollone R, Amelio I, Catani MV, Ramadan S, Browne G, Melino G and Candi E. Skn-1a/Oct-11 and DeltaNp63alpha exert antagonizing effects on human keratin expression. Biochem Biophys Res Commun. 2010; 401(4):568-573.

59. Celli J, Duijf P, Hamel BC, Bamshad M, Kramer B, Smits AP, Newbury-Ecob R, Hennekam RC, Van Buggenhout G, van Haeringen A, Woods CG, van Essen AJ, de Waal R, Vriend G, Haber DA, Yang A, et al. Heterozygous germline mutations in the p53 homolog p63 are the cause of EEC syndrome. Cell. 1999; 99(2):143-153.

60. Browne G, Cipollone R, Lena AM, Serra V, Zhou H, van Bokhoven H, Dotsch V, Merico D, Mantovani R, Terrinoni A, Knight RA, Candi E and Melino G. Differential altered 
stability and transcriptional activity of DeltaNp63 mutants in distinct ectodermal dysplasias. J Cell Sci. 2011; 124(Pt 13):2200-2207.

61. Yi R, Poy MN, Stoffel M and Fuchs E. A skin microRNA promotes differentiation by repressing 'stemness'. Nature. 2008; 452(7184):225-229.

62. Rivetti di Val Cervo P, Lena AM, Nicoloso M, Rossi S, Mancini M, Zhou H, Saintigny G, Dellambra E, Odorisio T, Mahe C, Calin GA, Candi E and Melino G. p63-microRNA feedback in keratinocyte senescence. Proc Natl Acad Sci U S A. 2012; 109(4):1133-1138.

63. Lena AM, Shalom-Feuerstein R, Rivetti di Val Cervo P, Aberdam D, Knight RA, Melino G and Candi E. miR-203 represses 'stemness' by repressing DeltaNp63. Cell Death Differ. 2008; 15(7):1187-1195.

64. Chakravarti D, Su X, Cho MS, Bui NH,Coarfa C, Venkatanarayan A, Benham AL, Flores Gonzalez RE, Alana J, Xiao W, Leung ML, Vin H, Chan IL, Aquino A, Muller N, Wang H, et al. Induced multipotency in adult keratinocytes through down-regulation of DeltaNp63 or DGCR8. Proc Natl Acad Sci U S A. 2014.

65. Viticchie G, Lena AM, Cianfarani F, Odorisio T, Annicchiarico-Petruzzelli M, Melino G and Candi E. MicroRNA-203 contributes to skin re-epithelialization. Cell Death Dis. 2012; 3:e435.

66. Freije JM, Diez-Itza I, Balbin M, Sanchez LM, Blasco $\mathrm{R}$, Tolivia $\mathrm{J}$ and Lopez-Otin C. Molecular cloning and expression of collagenase-3, a novel human matrix metalloproteinase produced by breast carcinomas. J Biol Chem. 1994; 269(24):16766-16773.

67. Welgus HG, Kobayashi DK and Jeffrey JJ. The collagen substrate specificity of rat uterus collagenase. J Biol Chem. 1983; 258(23):14162-14165.

68. Johansson N, Saarialho-Kere U, Airola K, Herva R, Nissinen L, Westermarck J, Vuorio E, Heino J and Kahari VM. Collagenase-3 (MMP-13) is expressed by hypertrophic chondrocytes, periosteal cells, and osteoblasts during human fetal bone development. Dev Dyn. 1997; 208(3):387-397.

69. Stickens D, Behonick DJ, Ortega N, Heyer B, Hartenstein B, Yu Y, Fosang AJ, Schorpp-Kistner M, Angel P and Werb Z. Altered endochondral bone development in matrix metalloproteinase 13-deficient mice. Development. 2004; 131(23):5883-5895.

70. Inada $\mathrm{M}$, Wang $\mathrm{Y}$, Byrne $\mathrm{MH}$, Rahman MU, Miyaura C, Lopez-Otin C and Krane SM. Critical roles for collagenase-3 (Mmp13) in development of growth plate cartilage and in endochondral ossification. Proc Natl Acad Sci U S A. 2004; 101(49):17192-17197.

71. Mitchell PG, Magna HA, Reeves LM, Lopresti-Morrow LL, Yocum SA, Rosner PJ, Geoghegan KF and Hambor JE. Cloning, expression, and type II collagenolytic activity of matrix metalloproteinase-13 from human osteoarthritic cartilage. J Clin Invest. 1996; 97(3):761-768.

72. Johansson N, Westermarck J, Leppa S, Hakkinen L,
Koivisto L, Lopez-Otin C, Peltonen J, Heino J and Kahari VM. Collagenase 3 (matrix metalloproteinase 13) gene expression by $\mathrm{HaCaT}$ keratinocytes is enhanced by tumor necrosis factor alpha and transforming growth factor beta. Cell Growth Differ. 1997; 8(2):243-250.

73. Hattori N, Mochizuki S, Kishi K, Nakajima T, Takaishi H, D'Armiento J and Okada Y. MMP-13 plays a role in keratinocyte migration, angiogenesis, and contraction in mouse skin wound healing. Am J Pathol. 2009; 175(2):533546.

74. Amelio I, Lena AM, Viticchie G, Shalom-Feuerstein R, Terrinoni A, Dinsdale D, Russo G, Fortunato C, Bonanno E, Spagnoli LG, Aberdam D, Knight RA, Candi E and Melino G. miR-24 triggers epidermal differentiation by controlling actin adhesion and cell migration. J Cell Biol. 2012; 199(2):347-363.

75. Oberoi-Khanuja TK, Murali A and Rajalingam K. IAPs on the move: role of inhibitors of apoptosis proteins in cell migration. Cell Death Dis. 2013; 4:e784.

76. Beare AH, Krane SM and Ferguson MW. Variable impairment of wound healing in the heterozygous collagenase-resistant mouse. Wound Repair Regen. 2005; 13(1):27-40.

77. Balbin M, Fueyo A, Knauper V, Lopez JM, Alvarez J, Sanchez LM, Quesada V, Bordallo J, Murphy G and LopezOtin C. Identification and enzymatic characterization of two diverging murine counterparts of human interstitial collagenase (MMP-1) expressed at sites of embryo implantation. J Biol Chem. 2001; 276(13):10253-10262.

78. Fuchs E and Horsley V. More than one way to skin. Genes Dev. 2008; 22(8):976-985.

79. Hartenstein B, Dittrich BT, Stickens D, Heyer B, Vu TH, Teurich S, Schorpp-Kistner M, Werb Z and Angel P. Epidermal development and wound healing in matrix metalloproteinase 13-deficient mice. J Invest Dermatol. 2006; 126(2):486-496.

80. Radisky DC, Levy DD, Littlepage LE, Liu H, Nelson CM, Fata JE, Leake D, Godden EL, Albertson DG, Nieto MA, Werb Z and Bissell MJ. Rac1b and reactive oxygen species mediate MMP-3-induced EMT and genomic instability. Nature. 2005; 436(7047):123-127.

81. Kesanakurti D, Chetty C, Rajasekhar Maddirela D, Gujrati M and Rao JS. Functional cooperativity by direct interaction between PAK4 and MMP-2 in the regulation of anoikis resistance, migration and invasion in glioma. Cell Death Dis. 2012; 3:e445.

82. Huang MY, Chang HJ, Chung FY, Yang MJ, Yang YH, Wang JY and Lin SR. MMP13 is a potential prognostic marker for colorectal cancer. Oncol Rep. 2010; 24(5):12411247.

83. Kalva S, Saranyah K, Suganya PR, Nisha M and Saleena LM. Potent inhibitors precise to S1' loop of MMP-13, a crucial target for osteoarthritis. J Mol Graph Model. 2013; 44:297-310. 
84. Intekhab-Alam NY, White OB, Getting SJ, Petsa A, Knight RA, Chowdrey HS, Townsend PA, Lawrence KM and Locke IC. Urocortin protects chondrocytes from NOinduced apoptosis: a future therapy for osteoarthritis? Cell Death Dis. 2013; 4:e717.

85. Zeisel MB, Druet VA, Wachsmann D and Sibilia J. MMP-3 expression and release by rheumatoid arthritis fibroblastlike synoviocytes induced with a bacterial ligand of integrin alpha5beta1. Arthritis Res Ther. 2005; 7(1):R118-126.

86. Chang HJ, Yang MJ, Yang YH, Hou MF, Hsueh EJ and Lin SR. MMP13 is potentially a new tumor marker for breast cancer diagnosis. Oncol Rep. 2009; 22(5):1119-1127.

87. Zhang B, Cao X, Liu Y, Cao W, Zhang F, Zhang S, Li H, Ning L, Fu L, Niu Y, Niu R, Sun B and Hao X. Tumorderived matrix metalloproteinase-13 (MMP-13) correlates with poor prognoses of invasive breast cancer. BMC Cancer. 2008; 8:83.

88. Inoue $\mathrm{S}$, Tomasini R, Rufini A, Elia AJ, Agostini M, Amelio I, Cescon D, Dinsdale D, Zhou L, Harris IS, Lac S, Silvester J, Li WY, Sasaki M, Haight J, Brustle A, et al. TAp73 is required for spermatogenesis and the maintenance of male fertility. Proc Natl Acad Sci U S A. 2014.

89. Quandt K, Frech K, Karas H, Wingender E and Werner T. MatInd and MatInspector: new fast and versatile tools for detection of consensus matches in nucleotide sequence data. Nucleic Acids Res. 1995; 23(23):4878-4884.

90. Ribelles N, Santonja A, Pajares B, Llacer C and Alba E. The seed and soil hypothesis revisited: current state of knowledge of inherited genes on prognosis in breast cancer. Cancer Treat Rev. 2014; 40(2):293-299.

91. Insabato L, Amelio I, Quarto M, Zannetti A, Tolino F, de Mauro G, Cerchia L, Riccio P, Baumhoer D, Condorelli G, Terracciano L and de Franciscis V. Elevated expression of the tyrosine phosphatase SHP-1 defines a subset of highgrade breast tumors. Oncology. 2009; 77(6):378-384.

92. Papi A, Guarnieri T, Storci G, Santini D, Ceccarelli C, Taffurelli M, De Carolis S, Avenia N, Sanguinetti A, Sidoni A, Orlandi $\mathrm{M}$ and Bonafe $\mathrm{M}$. Nuclear receptors agonists exert opposing effects on the inflammation dependent survival of breast cancer stem cells. Cell Death Differ. 2012; 19(7):1208-1219.

93. Pencheva N, Tran H, Buss C, Huh D, Drobnjak M, Busam $\mathrm{K}$ and Tavazoie SF. Convergent multi-miRNA targeting of ApoE drives LRP1/LRP8-dependent melanoma metastasis and angiogenesis. Cell. 2012; 151(5):1068-1082.

94. Kim M, Gans JD, Nogueira C, Wang A, Paik JH, Feng B, Brennan C, Hahn WC, Cordon-Cardo C, Wagner SN, Flotte TJ, Duncan LM, Granter SR and Chin L. Comparative oncogenomics identifies NEDD9 as a melanoma metastasis gene. Cell. 2006; 125(7):1269-1281.

95. Romano S, Staibano S, Greco A, Brunetti A, Nappo G, Ilardi G, Martinelli R, Sorrentino A, Di Pace A, Mascolo M, Bisogni R, Scalvenzi M, Alfano B and Romano MF. FK506 binding protein 51 positively regulates melanoma stemness and metastatic potential. Cell Death Dis. 2013; 4:e578.

96. Wang Y, Yang F, Zhang HX, Zi XY, Pan XH, Chen F, Luo WD, Li JX, Zhu HY and Hu YP. Cuprous oxide nanoparticles inhibit the growth and metastasis of melanoma by targeting mitochondria. Cell Death Dis. 2013; 4:e783.

97. Loi S, Haibe-Kains B, Desmedt C, Lallemand F, Tutt AM, Gillet C, Ellis P, Harris A, Bergh J, Foekens JA, Klijn JG, Larsimont D, Buyse M, Bontempi G, Delorenzi M, Piccart MJ, et al. Definition of clinically distinct molecular subtypes in estrogen receptor-positive breast carcinomas through genomic grade. J Clin Oncol. 2007; 25(10):12391246.

98. Haqq C, Nosrati M, Sudilovsky D, Crothers J, Khodabakhsh D, Pulliam BL, Federman S, Miller JR, 3rd, Allen RE, Singer MI, Leong SP, Ljung BM, Sagebiel RW and Kashani-Sabet M. The gene expression signatures of melanoma progression. Proc Natl Acad Sci U S A. 2005; 102(17):6092-6097.

99. Sun Y, Cheung JM, Martel-Pelletier J, Pelletier JP, Wenger L, Altman RD, Howell DS and Cheung HS. Wild type and mutant p53 differentially regulate the gene expression of human collagenase-3 (hMMP-13). J Biol Chem. 2000; 275(15):11327-11332. 